\title{
Clinical and Biochemical Correlations Obesity - HDL Cholesterol- Ischemic Coronary Heart Disease
}

\author{
NIKOLAOS MAVRITSAKIS ${ }^{1}$, BOGDAN VIRGIL COTOI2*, ANCA GANESCU3 ${ }^{3}$, ELENA IONESCU2* \\ ${ }^{1} 1$ Decembrie 1918 University of Alba Iulia,Facultaty of Law and Social Sciences, 5 Gabriel Bethlen Str., 510009,Alba Iulia, Romania \\ 2.University of Medicine and Pharmacy, 2 Petru Rares Str., 200349, Craiova, Romania \\ 3University of Craiova,Faculty of Sciences, Chemistry Departament,107I Calea Bucuresti, 200478, Craiova, Romania
}

\begin{abstract}
Central obesity is defined by increasing abdominal circumference ranging from certain limits to the characteristics of the ethnic groups of the rated person ( $>94 \mathrm{~cm}$ for European males and $>80 \mathrm{~cm}$ for Euclid women). The metabolic syndrome, commonly associated with central obesity, must meet at least two of the following four criteria:increased triglyceride levels> $159 \mathrm{mg} / \mathrm{dL}$ or specific treatment for this type of dyslipidemia; Low HDL-cholesterol < $40 \mathrm{mg} / \mathrm{dL}$ or specific treatment for this type of dyslipidemia; Increased blood pressure: Systolic BP $\geq 130 \mathrm{~mm}$ Hg or Diastolic BP $\geq 85 \mathrm{~mm} \mathrm{Hg}$, or HTA treatment previously diagnosed; High blood glucose level $\geq 100 \mathrm{mg} / \mathrm{dL}$ or type 2 diabetes diagnosed previously. HDL-cholesterol (HDL-C) is a group of lipoproteinssynthesized and secreted by hepatocytes. HDL plays an important role in the metabolism of cholesterol, participating in its transport from extrahepatic tissues to the liver for catabolism and excretion.. HDL and LDL participate in maintaining cell cholesterol levels. HDL-cholesterol and apolipoprotein-A values are positive atherosclerosis risk factors. The high level of HDL-C protects the patient, with a low risk of atherosclerosis HDL dosing is done for assessing the risk of coronary artery disease; diagnosis of hyperlipoproteinemia. Increased body weight is associated with increased total mortality and morbidity due to cardiovascular disease, partly mediated by increased blood pressure and cholesterol, lowering HDL-cholesterol and increasing the likelihood of diabetes.
\end{abstract}

Keywords HDL-cholesterol, obesity, coronary ischemic disease.

Epidemiological studies have confirmed in recent years that patients with low HDL-cholesterol levels are at high risk of developing coronary artery disease and myocardial infarction $[1,2]$.

The prolongation of circulating persistence of TG-rich lipoproteins leads to an increase in TG exchange from these particles with HDL2 and LDL-cholesterol esters (type A).

These lipid shifts are mediated by the esterified cholesterol transfer protein (CETP) and cause the HDL2 and LDL content to decrease in cholesterol and increase the TG in cholesterol.

TG from the HDL2 and LDL particles are lysed under the action of hepatic lipase and, after this intervention, result in smaller and more dense HDL3 and LDL particles.

Low HDL3 and small and dense LDL particles are rapidly removed from the circulation, which contributes to lowering plasma HDL $[3,4]$. In the Framingham Hearth Study and Quebec Cardiovascular Study, the total / HDLC cholesterol ratio was the highest predictive value lipid index.

\section{Experimental part}

This study evaluated patients diagnosed with obesity in which we quantified the degree of abdominal obesity (CMA), we compared gender, age, evaluated cardiovascular function (presence of hypertension, ischemic coronary artery disease), we studied the presence of disorders endocrine associated by evaluating thyreotropic and corticotrope axes by TSH, FT4, ACTH and cortisol dosing (table 1) and followed the HDL-cholesterol plasma dynamics.

To assess cardiovascular risk we determined HDLcholesterol, knowing that many epidemiological studies have shown that patients with low plasma levels are at increased risk for coronary heart disease and myocardial infarction[5,6].Patient preparation requires that the patient observe a diet unchanged for 3 weeks before harvesting; -have a constant weight; [ 7].

-not to eat 12-14 $\mathrm{h}$ before harvesting (can drink water and black coffee without sugar);

Abstinence from alcohol is recommended $72 \mathrm{~h}$ before harvesting;

Dosing technique for HDL cholesterol. Specimen harvested - venous blood [8, 14].

Vacuum container without anticoagulant with / without separator gel.

Processing required after harvest - separate the serum by centrifugation; work the same day or store at $4^{\circ} \mathrm{C}$ times $-20^{\circ} \mathrm{C}$.

Volume sample - minimum $0.5 \mathrm{~mL}$ ser

Causes of sample rejection - hemolyzed intensive specimen.

Stability of the test sample is stable for 5-7 days at 2-8 ${ }^{\circ}$

C; 3 months at $-20^{\circ} \mathrm{C}$; a few years at $-70^{\circ} \mathrm{C}$

Method - spectrophotometric (enzymatic).

\begin{tabular}{|c|c|}
\hline Interpretation & Values (mg/ dL) \\
\hline Normal & $>40$ \\
\hline Protector factor & $>60$ \\
& \\
\hline
\end{tabular}

Table 1

REFERENCE VALUES 


\begin{tabular}{|c|c|}
\hline Increases & decreases \\
\hline $\begin{array}{l}\text {-intense and lasting physical effort, } \\
\text {-moderate alcohol consumption } \\
\text {-insulin treatment; } \\
\text {-clofibrate, gemfibrozil, lovastatin, pravastatin, } \\
\text { simvastatin, nicotinic acid, phenobarbital, } \\
\text { phenytoin, prazosin, terazosin, terbutaline, } \\
\text { captopril, carbamazepine, coenzyme Q10, } \\
\text { furosemide, insulin, ketoconazole, } \\
\text { medroxyprogesterone, niacin, nifedipine, } \\
\text { verapamil, etc.; } \\
\text {-Analytical interference: Increased } \\
\text { immunoglobulin concentration causes a false } \\
\text { increase in HDL }\end{array}$ & $\begin{array}{l}\text { - inantion and anorexia } \\
\text { - smoking } \\
\text {, - stress and recent illness (IMA, stroke, } \\
\text { surgery, trauma), } \\
\text { - obesity [13,14] } \\
\text { - lack of physical training } \\
\text { - hipertrigliceridemie; } \\
\text { - drugs: androgens, beta blockers } \\
\text { (especially noncardioselective), acid } \\
\text { chenodeoxycholic, cyclosporin A, } \\
\text { ciproterone acetate (high doses), } \\
\text { danazol, diuretics, etretinate, } \\
\text { interferon, interleukin, isotretinoin, } \\
\text { medroxyprogesterone, probucol, } \\
\text { progestative, thiazide; }\end{array}$ \\
\hline
\end{tabular}

Table 2

VARIATION OF HDL-CHOLESTEROL
Total cholesterol / HDL7 ratio:

Low risk: 3.3-4.4

Average risk: 4.4-7.1

Moderate risk: 7.1-11

Increased risk:> 11

Conversion factor: $\mathrm{mg} / \mathrm{dL} \times 0.026=\mathrm{mmol} / \mathrm{L}$

Detection limit - $0.08 \mathrm{mmol} /(3 \mathrm{mg} / \mathrm{dL})[8,9]$.

Clinical alert values - $<40 \mathrm{mg} / \mathrm{dL}$ : are associated with

increased risk of coronary artery disease [10-12]

The results are presented in table 2 .

\section{Determination of anthropometric indices}

CFA was measured with the metric band in a horizontal plane passing through the middle of the distance between the lower edge of the ribs and the iliac crest as recommended by IDF

It correlates with intraabdominal fat mass: values greater than or equal to $94 \mathrm{~cm}$ in men, and greater than or equal to $80 \mathrm{~cm}$ in women, are considered an increased risk for cardiovascular morbidity and mortality.

Methods of statistical and mathematical processing used

SPSS, specialized in statistical statistical calculations, produced by SPSS and the Data Analysis module of MICROSOFT EXCEL, together with the XLSTAT suite for MS Excel, were used for data processing.

The Chi square test was used to interpret the incidence tables; the data were appreciated from the point of view of the dependence between the two classification factors, retaining only the results below $5 \%$, considered a sufficient materiality threshold

The test shows whether there is any relationship (mutual influence) between the two factors analyzed by the scorecard $[15,16]$.

In the quadratic test for the dependence test between two factors, the test result for the data from the incidence tables was calculated, a result that was compared to the threshold value indicating a significant dependence $(95 \%$ or $99 \%$ threshold) or a high significant dependence threshold of $99.9 \%$ ) between the two classification factors $[15,16]$.

$$
\chi^{2}=\sum_{i=1}^{n} \frac{\left(\left|O_{i}-E_{i}\right|\right)^{2}}{E_{i}}
$$

where: $\mathrm{O}$ is the observed frequency, and $\mathrm{E}$ is the theoretical frequency

The Chi square test is valid if at least $80 \%$ of the probable frequencies exceed 5 and all probable frequencies exceed 1.
We used the following interpretation of the $p$ values, provided directly by the program with which the statistical data processing is performed, by applying the above test: $-p<0.05$, the difference between the two media is significant (S);

$-p<0.01$, the difference between the two media is highly significant (HS);

$-p<0.001$, the difference between the two media is very high (VHS);

$-p>0.05$, the difference between the two media is insignificant (NS).

The Cramer test verifies the association power between two nominal factors and is used for multi-row tables and columns (for tables $2 \times 2$ the phi coefficient is preferred), more precisely measures if each category of one of the factors is preferentially associated with one of categories of the other factors

The result of this test is recorded with $\mathrm{V}$.

$$
V=\sqrt{\chi^{2} / \min (r-1, c-1)}
$$

where $r$ and $c$ are the number of rows and columns in the studied incidence table.

The Student $t$ test of comparing the averages for two lots proposes two statistical hypotheses:

-HO hypothesis (or null hypothesis): the difference between environments is incidental;

-H1 hypothesis: the difference between averages is statistically significant

The $p$ result of the test is probability of making an error if the hypothesis $\mathrm{HO}$ of the test is rejected, a result provided as a number between 0 and 1 .

If $p$ is less than 0.05 , we reject the hypothesis $\mathrm{HO}$, the null, and admit that the hypothesis $\mathrm{H} 1$ is true.

In the comparing test of the media (Student test), we used the following interpretation of the values of $p$, povided directly by the program with which the statistical processing of the data is performed, by applying the above test:

$-p<0.05$, the difference between the two media is significant ( $\mathrm{S}$ );

$-p<0.01$, the difference between the two media is highly significant (HS);

$-p<0.001$, the difference between the two media is very high (VHS);

$-p>0.05$, the difference between the two media is insignificant (NS).

\section{Results and discussions}

In the study, we had 118 women and 54 men, the gender distribution of HDL was the following (table 3 , fig. 1) 


\begin{tabular}{|c|l|l|l|l|c|}
\hline HDL & \multicolumn{2}{|c|}{ scăzut } & \multicolumn{2}{c|}{ normal } & \multirow{2}{*}{ Total } \\
\cline { 1 - 5 } Sex & Ladies & Men & Ladies & Men & \\
\hline $\begin{array}{l}\text { Percentage } \\
\text { value }\end{array}$ & $20.35 \%$ & $26.16 \%$ & $48.26 \%$ & $5.23 \%$ & $100.00 \%$ \\
\hline
\end{tabular}

Table 3

DISTRIBUTION OF HDLC BY SEX

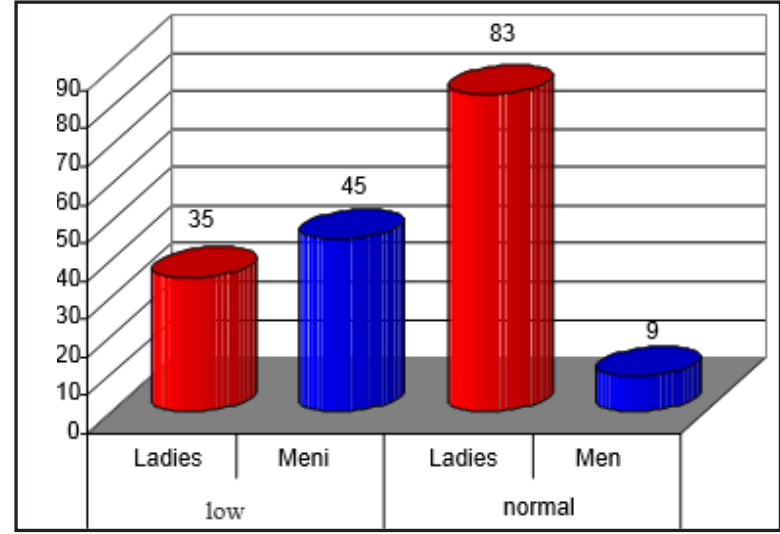

HDL Level

Fig. 1. HDLC distribution by gender

$-48.26 \%$ of women and $5.23 \%$ of men showed normal $\mathrm{HDL}$ (greater than or equal to $50 \mathrm{mg} / \mathrm{dL}$ for women and greater than or equal to $40 \mathrm{mg} / \mathrm{dL}$ for men);

-The remaining $20.35 \%$ of women and $26.16 \%$ of men had low HDL (below $50 \mathrm{mg} / \mathrm{dL}$ in women, respectively below $40 \mathrm{mg} / \mathrm{dL}$ in men).

-From this study, it results that a higher percentage of hipo-HDL cholesterol is compared with that of women (and therefore increased risk for atherosclerotic disease.

Depending on the association of obesity with endocrine changes we have divided the patients into 3 lots

- group I, patients with obesity not associated with endocrine disorders

- group II, patients with obesity associated with Cushing's disease

-group III, patients with obesity and hypothyroidism.

The batch distribution of HDL was as follows (table 4, table 5):

-In group 1 there were 46 patients (51.69\%) with normal $\mathrm{HDL}$ and 43 patients (48.31\%) with low HDL

-In group 2 there were 37 patients $(60.66 \%)$ with normal HDL and 24 (39.34\%) low HDL patients;

-9 patients (40.91\%) with normal HDL and 13 patients

(59.09\%) with low HDL were recorded in group 3.

The HDL-grade obesity correlation is as follows (fig. 2).

Table 4

Of the 59 patients with obesity, grade l: 1 patient (1.69\%) had a normal HDL and 58 patients (98.31\%), low HDL values;

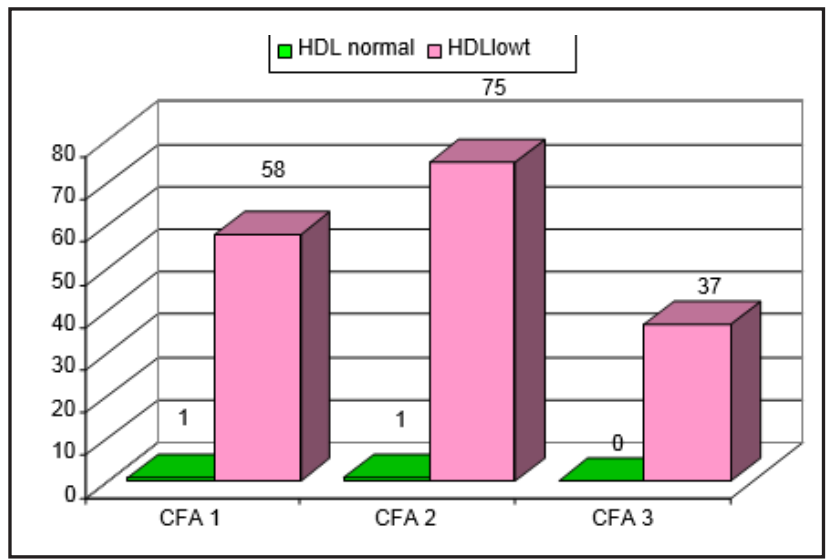

Fig. 2. The distribution of HDLC values based on the degree of obesity.

-Of the 76 patients with grade II obesity: 1 patient (1.32\%) had a normal HDL and 75 (98.68\%) low HDL.

-All 37 patients with grade III obesity had low HDL.

In conclusion, the degree of obesity and abdominal obesity is a risk factor for hipo-HDL cholesterol

. This is explained by the association of the hepatic AGL influx, which stimulates the hepatic synthesis of large TGrich VLDLs which, through changes after release into the bloodstream, will lead to increased plasma concentrations of small and dense LDL and decreased plasma HDLC.

Hypertriglyceridemia causes decreased plasma concentrations of HDL2 particles and increased HDL3

This change in HDL increases cardiovascular risk, as HDL2 particles have antiatherogenic effect.

HDL and LDL are independent predictors of cardiovascular risk.

Incidence of painful coronary artery disease

The distribution of patients with painful $\mathrm{BCl}$ by batch is as follows (table 6):

-In group 1: 28 patients (31.46\%) were diagnosed with

Painful $\mathrm{BCl}$ based on typical angina pain and ischemic changes on the resting ECG;

DISTRIBUTION OF MINIMUM, MEAN AND MAXIMUM VALUES OF HDLC BY LOTS

\begin{tabular}{|c|c|c|c|c|}
\hline HDL & Lot 1 & Lot 2 & Lot 3 & Total \\
\hline No. & 89 & 61 & 22 & 172 \\
\hline Minimum & 32 & 32 & 32.8 & 32 \\
\hline Maximum & 65 & 55 & 51 & 65 \\
\hline Average & 44.31 & 43.13 & 39.59 & 43.29 \\
\hline Dev.std. & 7.60 & 5.29 & 5.31 & 6.73 \\
\hline CV & $17.15 \%$ & $12.27 \%$ & $13.40 \%$ & $15.55 \%$ \\
\hline Test Student & L1-L2 & L1-L3 & L2-L3 & ANOVA \\
\hline P & 0.29406 & 0.00700 & 0.00873 & 0.01192 \\
\hline
\end{tabular}

Table 5

DISTRIBUTION OF HDLC BY LOTS

\begin{tabular}{|l|c|c|c|}
\hline HDL & Normal & Low & Total \\
\hline Lot I & 46 & 43 & 89 \\
\hline Lot II & 37 & 24 & 61 \\
\hline Lot III & 9 & 13 & 22 \\
\hline Total & 92 & 80 & 172 \\
\hline
\end{tabular}


Table 6

DISTRIBUTION OF PATIENTS WITH PAINFUL BCI BY LOT

\begin{tabular}{|l|c|c|c|}
\hline BCI painful & Yes & No & Total \\
\hline Lot 1 & 28 & 61 & 89 \\
\hline Lot 2 & 24 & 37 & 61 \\
\hline Lot 3 & 8 & 14 & 22 \\
\hline Total & 60 & 112 & 172 \\
\hline \multicolumn{4}{|c|}{ Table 7 }
\end{tabular}

DISTRIBUTION OF PATIENTS WITH BCI PAINLESS ON BATCHES

\begin{tabular}{|l|c|c|c|}
\hline BCI painless & Yes & No & Total \\
\hline Lot 1 & 18 & 71 & 89 \\
\hline Lot 2 & 15 & 46 & 61 \\
\hline Lot 3 & 8 & 14 & 22 \\
\hline Total & 41 & 131 & 172 \\
\hline
\end{tabular}

-In group 2: 24 patients (39.34\%) were diagnosed with painful $\mathrm{BCl}$, with suggestive clinical symptoms accompanied by electrocardiographic ischaemia;

-In group 3: 8 patients $(36.36 \%$ ) had painful $\mathrm{BCl}$, the remaining 14 patients (63.64\%) not experiencing typical angina pain.

There was no significant difference ( $p>0.05$ ) in the distribution of painful coronary artery disease in the three groups.

\section{Incidence of painless ischemic coronary heart disease}

The distribution of patients with $\mathrm{BCl}$ painless by lot is the following (table 7):

-In group 1, 18 patients (20.22\%) presented the $\mathrm{BCl}$ painless, diagnosed on

the basis of ischemic changes on the resting ECG in the absence of angina.

-In group 2, 15 patients (24.59\%) presented $\mathrm{BCI}$ painless and 46 patients

(75.41\%) had no ischemic changes on the resting ECG;

In group 3, 8 patients $(36.36 \%)$ presented painless $\mathrm{BCl}$ and 14 patients

(63.64\%) had no ischemic changes on the resting ECG.

\section{Conclusions}

HDL-cholesterol and apolipoprotein-A values are positive atherosclerosis risk factors.

The high level of HDL-C protects the patient, with a low risk of atherosclerosis

In this study, 54 men and 118 women were diagnosed with obesity: 82 women and 8 men had HDL slightly below normal (less than or equal to $50 \mathrm{mg} / \mathrm{dL}$ for women and less than or equal to $40 \mathrm{mg} / \mathrm{dL}$ for men), the remaining 35 women and 45 men had a very low HDL.

The degree of obesity and abdominal obesity is a risk factor for hipo-HDL cholesterol

This is explained by the association of the hepatic AGL influx, which stimulates the hepatic synthesis of large TGrich VLDLs which, through changes after release into the bloodstream, will lead to increased plasma concentrations of small and dense LDL and decreased plasma HDLC.

In patients with grade 1 obesity, 58 had low HDL cholesterol and one patient had normal, in those with obesity grade 75 they had low HDL cholesterol and one patient had normal, and in those with obesity Grade 337 patients representing the whole lot had low HDL cholesterol.

In the study, we identified $34.88 \%$ of patients with painful ischemic heart disease and $23.84 \%$ of patients with painless ischemic heart disease diagnosed on the basis of clinical picture and resting ECG, and after the exercise ECG test, another $4.65 \%$ of patients were diagnosed with $\mathrm{BCl}$.

There were no significant differences in the distribution of $\mathrm{BCl}$ per lot $(\mathrm{p}>0.05)$

\section{References}

1. BETTERIDGE, DJ . ,High Density Lipoprotein and Coronary Heart Disease. In BMJ 298(6679): 974-5. 1989. Ref Type: J ournal (Full).

2. CLEEMAN, JI. EXECUTIVE ,Summary of the Third Report of the National Cholesterol Education Program (NCEP) Expert Panel on Detection, Evalution and Treatment of High Blood Cholesterol in Adults. In JAMA 285: 2486-97. 2001. Ref Type: Journal (Full).

3. POPA CRISTEA, E., Metabolismul lipidelor. In Biochimie Medicala. Editura Medicala, Romania, 2 ed., 1998, 394-478.

4. FISCHBACH, F., Chemistry Studies. In A Manual of Laboratory and Diagnostic Tests. Lippincott Williams \& Wilkins, USA, 8 ed., 2009, 450452.

5. FISCHBACH, F., Effects of Drugs on Laboratory Tests. In A Manual of Laboratory and Diagnostic Tests. Lippincott Williams \& Wilkins, USA, 7 ed., 2004, 1243.

6. GORDON, DJ ., RIFKIND, BM., High Density Lipoprotein-the Clinical Implications of recent studies. In N Engl J Med 321(19): 1311-6. 1989. Ref Type: Journal (Full).

7. WALLACH, J., Boli metabolice si ereditare. In Interpretarea testelor de diagnostic. Editura Stiintelor Medicale, Romania, 7 ed., 2001, 653752.

8. LABORATOR SYNEVO., Referintele specifice tehnologiei de lucru utilizate 2010. Ref Type: Catalog.

9. *** LABORATORY CORPORATION OF AMERICA., Directory of Services and Interpretive Guide. High-Density Lipoprotein Cholesterol. www.labcorp.com 2010. Ref Type: Internet Communication.

10.MACIEJ KO, J ., HOLMES, DR., KOTTKE, BA., ET ALL,. Apolipoprotein A-1 as a Marker of Angiographically Assessed Coronary-Artery Disease. In N Engl J Med 309(7): 385-9. 1983. Ref Type: Journal (Full).

11. MILLER, NE., Association of High Density Lipoprotein Subclasses and Apolipoproteins with Ischemic Heart Disease and Coronary Atherosclerosis. In Am Heart] 113(2 ): 587-97. 1987. Ref Type: J ournal (Full).

12. TOTH, P., The Good Cholesterol,. High-density Lipoprotein. In Circulation 111: 89-91. 2005. Ref Type: J ournal (Full).

13. MAVRITSAKIS, N., URSU, V.E., GANESCU, A., IONESCU, E., Clinical and Biological Study on the Relevance of Hiperfibrinogenemyme in Cardiovascular Pathology of the Obez, Rev. Chim.(Bucharest), 70, no. 3,2019,p. 950-955.

14. IONESCU, E., CHIRITA ,A., COTOI, B.V., GANESCU, A., Hyperproduction Hydrogenic of STH Patology Generation of Clinical paraclinical Disorde, Rev.Chim.(Bucharest),70, no. 4 , 2019, p. 13191321

15. MAVRITSAKIS, N., URSU, V.E., IONESCU, E., GANESCU, A., Actual Study Regarding Quantitative Determination of Tetracyclines by Electrical Analysis Techniques and Methods Potentiometric sensors for tetracycline, Rev. Chim.(Bucharest), 70,no. 2, 2019, p. 671-675.

16. POPESCU, IG.,SECHEL, G.,LEASU, FG., TANTU, MM., COTOI, BV., ROGOZEA, LM., Correlations on the protection of personal data and intellectual property rights in medical research, Rom.J. Morphol.Embryol,59(3),2018,pag 1001-1005.

Manuscript received: 23.10 .2018 